\title{
Protein metabolism in the pectoralis muscle and liver of hibernating bats, Eptesicus fuscus
}

\author{
Marshall E. Yacoe* \\ Division of Biological Sciences, University of Michigan, Ann Arbor, Michigan 48109, USA \\ Accepted April 26, 1982
}

\begin{abstract}
Summary. Seasonal variations in protein metabolism of the pectoralis muscle and liver of the big brown bat, Eptesicus fuscus, are examined in relation to seasonal changes in physiological status. A technique is described for the determination of protein synthetic rates in vivo in animals too small for conventional methods. The results indicate no detectable rates of protein synthesis in hibernating bats during torpor bouts (Table 2). Rates of synthesis in hibernating bats during periods of arousal are comparable to those of active summer bats (Table 2), despite the fact that the hibernating bats had not eaten in over 2 months. Rates of protein degradation were calculated from the rate of urea formation in torpid bats (Figs. 4, 5), the overall loss of pectoralis muscle and liver protein mass during hibernation (Table 3), the proportion of the total time of hibernation spent in torpor and arousal (Table 1), and the observed rates of protein synthesis (Table 2). These estimates (Table 4) indicate negligible rates of protein degradation in torpid bats. However, protein degradation during periodic arousals is comparable to that of summer bats after an overnight fast. These findings are consistent with earlier observations suggesting that significant gluconeogenesis from tissue protein occurs during spontaneous arousals from hibernation.
\end{abstract}

\section{Introduction}

The big brown bat, Eptesicus fuscus, is a common insectivorous species ranging throughout much of

\footnotetext{
* Present address: Marine Biology Division, A-002, Scripps Institution of Oceanography, University of California San Diego, La Jolla, California 92093, USA
}

the continental United States and southern Canada. These bats do not undergo seasonal migrations (Beer 1955). Rather, they hibernate locally during winter, even at the northern end of their range, where the first and last killing frosts may be separated by as much as six months (see Beer and Richards 1956). Hibernation is thought to be a period of total fasting for these and other insectivorous bats since flying insects are scarce or absent during winter months and bats do not cache food.

The energetic requirements of E. fuscus during hibernation are met primarily by the oxidation of fat reserves which were accumulated the previous fall (Beer and Richards 1956; Yacoe 1983). However, E. fuscus also experiences significant decreases in lean mass, pectoralis muscle mass, and total pectoralis muscle protein, indicating significant oxidation of tissue protein during hibernation (Yacoe 1983). Similar relative decreases in lean mass and total body protein have also been observed in hibernating arctic ground squirrels (Galster and Morrison 1976). The observation that hibernating mammals appear to oxidize tissue protein is not surprising in light of the fact that net protein catabolism appears to be a universal feature of fasting in nonhibernating mammals (see Felig 1979) and birds (see Le Maro et al. 1981). However, these observations pose the question of how protein metabolism is regulated during hibernation since excessive degradation of tissue protein could compromise the ability to fly, a lethal condition for an animal which must fly to feed.

The present study examines protein metabolism in hibernating bats in relation to the patterns observed in fasting nonhibernating mammals. Protein metabolism undergoes time-dependent changes during fasting in nonhibernating mammals. During short-term fasting (1-2 days) the rate of protein degradation remains the same or is increased rela- 
tive to that of the fed state, whereas synthetic rates drop significantly (see Millward and Waterlow 1978; Li et al. 1979), leading to a rapid loss of total body protein (see Goodman and Ruderman 1980). The amino acids released from degraded proteins are used in synthesis of other proteins or they are oxidized, either directly, via the citric acid cycle, or indirectly, via gluconeogenesis. As fasting progresses (in animals capable of prolonged fasting), gluconeogenic demand decreases gradually and there is a progressive decrease in the rate of net protein loss until fat reserves are depleted (see Cahill 1976; Le Maro et al. 1981). Protein synthesis also slows down as fasting progresses (Millward and Waterlow 1978).

The caloric equivalent of the amount of total body protein lost by $E$. fuscus during 4 months of hibernation corresponds to approximately $10 \%$ of the energetic expenditure during that period (calculated either as a fraction of the total caloric content of the combined decrease in protein and fat mass or as a fraction of the estimated total metabolic expenditure [see Yacoe 1982]). This proportion is much lower than that observed in nonhibernators in short-term fasting, but is similar to that of obese humans (see Felig 1979) and obese geese (see Le Maro et al. 1981) after prolonged fasting. Therefore, the overall loss of protein relative to overall metabolic expenditure during hibernation in E. fuscus is similar to that in prolonged fasting of nonhibernating mammals, suggesting that protein catabolism may decrease during hibernation as it does during prolonged fasting. However, hibernation differs from prolonged fasting in that it is not a uniform physiological state. Hibernation consists of a series of torpor bouts, during which body temperature is allowed to fall to ambient levels and metabolism is very low. Torpor bouts account for virtually all of the time in hibernation, but less than $20 \%$ of the metabolic expenditure (Wang 1978; Yacoe 1982; Table 1). Torpor bouts are separated by periodic arousals, during which body temperature is briefly restored to normothermic levels. Arousals account for very little of the time, but over $80 \%$ of the metabolic expenditure of hibernation (see Wang 1978; Yacoe 1982; Table 1). In view of the metabolic heterogeneity of hibernation, two distinct patterns of protein metabolism could account for the low overall rate of protein loss observed in E. fuscus: (1) hibernation could resemble long-term fasting, with a progressive decrease in the rates of protein synthesis and degradation or (2) the low rate of protein loss could result primarily from a very low rate of protein degradation during torpor bouts, with little or no time-dependent change in the rate of degradation in either the torpid or aroused states. The present study attempts to evaluate these two possibilities.

\section{Materials and methods}

Animals. Bats were captured in barns and attics in the vicinity of Ann Arbor, Michigan. 'Summer' animals were captured in their day roosts, held overnight at room temperature, and used the following day. 'Hibernating' bats were captured in late September and early October, when they were quite fat, but still occasionally active. They were induced to hibernate in the laboratory in a darkened chamber at $5-7^{\circ} \mathrm{C}$ and approximately $100 \%$ relative humidity, conditions approximating those of natural hibernacula (Beer and Richards 1956). The bats used for protein synthesis measurements were housed together in a large cage. The remaining bats, which were used to determine the frequency and duration of torpor bouts and arousals and plasma and urinary urea levels, were housed individually in onegallon paint cans fitted with a cardboard structure into which they could climb and hang. A copper-constantan thermocouple was attached to this structure to provide a continuous record of air temperature inside the can. Dampened wood shavings provided a water-saturated atmosphere.

Torpor bouts and arousals. Can and cold room texperatures were recorded continuously during November and December, 1981 , for a total of $13,632 \mathrm{~h}$ of observation. When bats were torpid, the can temperature was indistinguishable from that of the cold room. When they underwent spontaneous arousal, the can temperature became elevated approximately $5^{\circ} \mathrm{C}$ relative to the cold room, allowing easy determination of torpor bout duration, arousal frequency, and arousal duration.

Plasma and urinary urea. Bats which had been torpid for various intervals were removed from their chambers and sacrificed by decapitation. Blood was collected in heparinized tubes and centrifuged at top speed in a clinical centrifuge. The plasma was transferred to plastic vials and frozen on dry ice. Urine samples were drawn directly from the bladder with a Hamilton syringe and urine volume was noted to the nearest microliter. The samples were then transferred to plastic vials and frozen on dry ice. All samples were stored at $-70^{\circ} \mathrm{C}$ until analysis. Five animals were induced to arouse from torpor by removing their cans from the cold room and allowing them to remain undisturbed for one hour at room temperature. During this time all five bats aroused and remained normothermic (body temperature $=33.4 \pm 1.4^{\circ} \mathrm{C}$, range $=29-36^{\circ} \mathrm{C}$ ). At the end of the hour the bats were sacrificed and samples were taken as above. All five bats had urinated during this period, but the urine was not collected. The urea concentration in plasma and urine samples was assayed by the coupled ureaseglutamate dehydrogenase method (Sigma tech. bull. no. 65-UV).

Protein synthesis. Freshly captured summer bats were fasted overnight and used the following day. Winter bats were held in hibernation for two months prior to use. After this period they were removed from the environmental chamber and allowed to arouse undisturbed for approximately one hour. During this time the bats achieved body temperatures of $30-35^{\circ} \mathrm{C}$. Fifteen of these bats were used immediately. The remaining eight were returned to the chamber overnight. All of these animals had re-entered the torpid state by the following day when they were used in protein synthesis experiments. Since hiberna- 
tors are refractory to external stimuli during the early part of a torpor bout (Galster and Morrison 1975), this protocol ensured that all of the torpid bats were in a refractory state, making it possible to handle and inject them without inducing arousal.

Protein synthesis was measured using a method based on that of Garlick et al. (1980). In all cases the bats were given an intraperitoneal injection $(0.01 \mathrm{ml} / \mathrm{g}$ body mass $)$ of $150 \mathrm{mM}$ phenylalanine in $0.9 \% \mathrm{NaCl}$, labelled with $50 \mu \mathrm{Ci} / \mathrm{ml} \mathrm{L}-\left[4-{ }^{3} \mathrm{H}\right]-$ phenylalanine (New England Nuclear). Intraperitoneal injection was necessary because these bats are too small to be reliably injected intravenously. After injection, summer bats and bats aroused from hibernation were allowed to rest undisturbed at room temperature and torpid bats were allowed to rest undisturbed at $3{ }^{\circ} \mathrm{C}$ prior to sacrifice. Initial samples were taken $10 \mathrm{~min}$ after injection to allow the label to equilibrate with plasma and intracellular amino acid pools (see Figs. 2, 3). Bats were sacrificed at the designated times by decapitation and blood was collected in heparinized tubes on ice. Then the pectoralis muscles (both sides) and liver were rapidly excised and frozen on dry ice. The blood samples were centrifuged for $10 \mathrm{~min}$ at top speed in a clinical centrifuge. Plasma samples $(50 \mu \mathrm{l})$ were collected and frozen on dry ice. All samples were held at $-70^{\circ} \mathrm{C}$ prior to analysis. In summer bats and aroused bats blood samples were collected at 10,20 , and $30 \mathrm{~min}$ after injection. Samples of pectoralis muscle and liver were frozen approximately 2 and $3 \mathrm{~min}$, respectively, following sacrifice. Torpid bats were sacrificed and blood samples were taken 10 and 120 min after injection. Muscle and liver samples were frozen approximately 2 and $3 \mathrm{~min}$, respectively, after sacrifice. Since the rate of protein synthesis is calculated from the change in specific activity of protein-bound phenylalanine between 10 and $30 \mathrm{~min}$ (for normothermic bats) or between 10 and $120 \mathrm{~min}$ (for torpid bats) all data are reported at the nominal times of $10,20,30$, and 120 min.

Sample preparation. The muscle and liver samples were sliced with a razor blade while still frozen and rapidly homogenized in $3 \mathrm{ml}$ of ice-cold $2 \% \mathrm{HClO}_{4}$ using a Tekmar Tissumizer set at top speed. Protein was removed from the plasma samples by similarly homogenizing $50 \mu 1$ of plasma in $3 \mathrm{ml}$ of ice-cold $2 \% \mathrm{HClO}_{4}$. These homogenates were centrifuged for $10 \mathrm{~min}$ at top speed in a clinical centrifuge. The supernatants were decanted into fresh tubes to which $1.5 \mathrm{ml}$ of a saturated tripotassium citrate solution was added (to precipitate the $\mathrm{HClO}_{4}$ ). This preparation was centrifuged again at top speed in a clinical centrifuge for $10 \mathrm{~min}$ and $1 \mathrm{ml}$ of the resulting supernatant was used for the determination of the specific activity of free phenylalanine in plasma, muscle, and liver. The $\mathrm{HClO}_{4}$ precipitates of muscle and liver protein were washed three times by resuspension in $5 \mathrm{ml}$ of $2 \% \mathrm{HClO}_{4}$, followed by centrifugation at top speed in a clinical centrifuge for $10 \mathrm{~min}$. The protein in the final precipitate was hydrolyzed in $5 \mathrm{ml}$ of $6 \mathrm{~N} \mathrm{HCl}$ for $24 \mathrm{~h}$ at $110^{\circ} \mathrm{C}$. These samples were then evaporated to dryness and resuspended in $3 \mathrm{ml}$ of $0.5 \mathrm{M}$ sodium citrate, $\mathrm{pH} 6.3$. A $1 \mathrm{ml}$ sample of this protein hydrolysate was used for determination of the specific activity of protein-bound phenylalanine in muscle and liver.

Specific activity of phenylalanine. Accurate determination of specific activity depends on the isolation of phenylalanine. The procedure used here (based on Garlick et al. 1980) involves the enzymatic decarboxylation of phenylalanine to $\beta$-phenethylamine (PEA) and the subsequent extraction and assay of PEA specific activity.

Aliquots ( $1 \mathrm{ml} \mathrm{each}$ ) of the supernatants from plasma, muscle, and liver samples, of the hydrolysates of muscle and liver

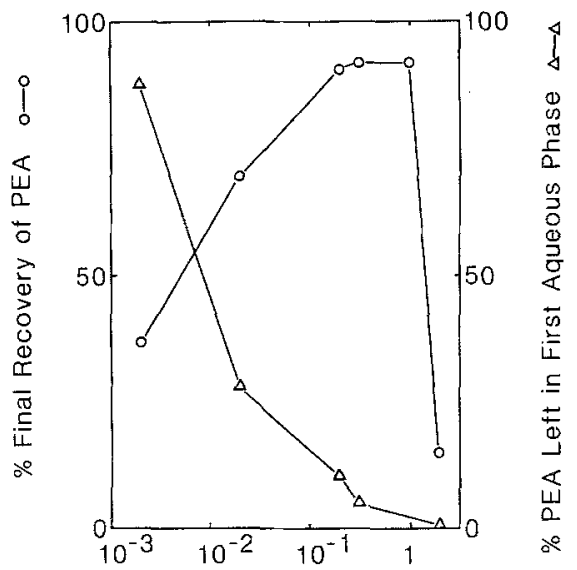

$\mathrm{NaOH}$ Concentration (M)

Fig. 1. The effect of $\mathrm{NaOH}$ concentration on the recovery of phenethylamine (PEA). The isolation of PEA is based on extraction into the organic phase at basic $\mathrm{pH}$ and subsequent extraction into the aqueous phase at acidic pH. Preliminary experiments showed that the recovery of PEA was maximized by sonication (for thorough mixing) and by adjustment of the $\mathrm{NaOH}$ concentration used in the first extraction to $0.5 \mathrm{M}$. The procedure described in the Materials and methods section resulted in over $90 \%$ recovery of both PEA and phenylalanine standards

protein, or of a standard solution of $20 \mu \mathrm{M}$ phenylalanine in $0.5 \mathrm{M}$ sodium citrate were incubated overnight in capped tubes at $37^{\circ} \mathrm{C}$ with $0.5 \mathrm{ml}$ of a suspension of $0.1 \mathrm{U}$ of phenylalanine decarboxylase (Sigma, P 2626) in $0.5 \mathrm{ml}$ sodium citrate, pH 6.3, containing $0.5 \mathrm{mg} / \mathrm{ml}$ pyridoxal phosphate as a cofactor. Under these conditions virtually $100 \%$ of the phenylalanine is converted to PEA. PEA was then extracted and assayed using a modification of the procedure of Suzuki and Yagi (1976), as follows. After enzymatic conversion to PEA, the samples were centrifuged for $10 \mathrm{~min}$ at top speed in a clinical centrifuge to pellet the enzyme. The supernatants were decanted into $30 \mathrm{ml}$ Corex centrifuge tubes and $1 \mathrm{ml}$ of $0.5 \mathrm{M} \mathrm{NaOH}(1.5 \mathrm{ml}$ for hydrolysates) and $10 \mathrm{ml}$ chloroform $/ \mathrm{n}$-heptane $(1: 3, \mathrm{v} / \mathrm{v})$ were added (see Fig. 1). This mixture was sonicated for $15 \mathrm{~s}$ at $40 \mathrm{~W}$ using a Branson Sonifier and then centrifuged for $10 \mathrm{~min}$ at $3,000 \mathrm{~g}$ to resolve the phases. The contents of each tube where then transferred to a separatory funnel, the aqueous (bottom) phase was discarded, and the organic (upper) phase was returned to the centrifuge tube. Then $5 \mathrm{ml}$ of chloroform and $4 \mathrm{ml}$ of $0.01 \mathrm{M} \mathrm{H}_{2} \mathrm{SO}_{4}$ were added and the mixture was sonicated and centrifuged as above. A $1 \mathrm{ml}$ sample $(2 \mathrm{ml}$ for hydrolysates) of the aqueous (upper) phase was removed for liquid scintillation counting in $10 \mathrm{ml}$ of a xylene based scintillant (Fricke 1975). A further $1 \mathrm{ml}$ aliquot $(20 \mu \mathrm{l}$ for hydrolysates) was analyzed for PEA concentration according to Suzuki and Yagi (1976).

Calculations and statistics. The rate of protein synthesis was calculated from the specific activities of free $\left(S_{a}\right)$ and proteinbound $\left(S_{b}\right)$ phenylalanine. The ratio of $S_{b} / S_{a}$ was calculated for each muscle and liver sample. Then the simple linear regression of $\left[\left(\mathrm{S}_{\mathrm{b}} / \mathrm{S}_{\mathrm{a}}\right) \times 100\right]$ on time since injection (in days) was calculated. The slope \pm the standard error of estimate of the regression line was used here as an estimate of the fractional rate of protein synthesis $(\% /$ day). The rates of protein synthesis in summer and winter bats were compared using analysis of covariance. Null hypotheses were rejected at the 0.01 level. 
Since there is no straightforward way to measure protein breakdown in vivo, rates of protein breakdown were calculated from the rates of synthesis and the net change in liver and muscle protein mass during hibernation according to the formula:

$$
\mathrm{FBR}=\mathrm{FSR}+\mathrm{FNL}
$$

where FBR is the fractional rate of protein breakdown (\%/day), FSR is the fractional rate of protein synthesis (\%/day), and FNL is the fractional rate of net protein loss (\%/day). Values for FNL in torpid bats were calculated from rates of urea accumulation (Figs. 5, 6). Values for FNL in hibernating bats during spontaneous arousal were calculated as the difference between the overall decrease in protein mass of pectoralis muscle and liver during hibernation (Table 2) and the amount which could be attributed to protein loss in torpor [calculated from FNL in torpor and the fraction of the total time of hibernation spent in torpor (Table 1)]. It was assumed that the fasted summer bats were in negative nitrogen balance, therefore FBR $>$ FSR. The potential for error is considerable and not quantifiable in the estimates of FNL in hibernating bats during spontaneous arousal and in fasted summer bats. Therefore, although numerical values are assigned to FBR, they are used only to make qualitative comparisons.

\section{Results}

\section{Torpor bouts and arousals}

Hibernation in E. fuscus consists of a series of torpor bouts averaging $155.3 \pm 9.0 \mathrm{~h}$ in duration, separated by periods of arousal averaging $3.2 \pm 0.2 \mathrm{~h}$ (Table 1). The duration of torpor bouts (range $=$ $17-471 \mathrm{~h}$ ) and arousals (range $=0.5-11.5 \mathrm{~h}$ ) both vary considerably. Of the $13,632 \mathrm{~h}$ of observation reported here, $98 \%$ of the time $(13,355 \mathrm{~h})$ was spent in torpor. The remaining $2 \%(277 \mathrm{~h})$ was spent in periods of spontaneous arousal (Table 1).

\section{Protein synthesis}

Protein synthetic rates were estimated in this study from the incorporation of $\mathrm{L}-\left[4-{ }^{3} \mathrm{H}\right]$-phenylalanine into pectoralis muscle and liver protein following the intraperitoneal injection of a single flooding dose. The validity of this method depends on three

Table 1. Duration of torpor and arousal during hibernation in $E$. fuscus

\begin{tabular}{|c|c|c|c|c|c|}
\hline Status & $\begin{array}{l}\text { Mean } \\
\text { duration } \\
\text { (h) }\end{array}$ & $\begin{array}{l}\text { Minimum } \\
\text { duration } \\
\text { (h) }\end{array}$ & $\begin{array}{l}\text { Maximum } \\
\text { duration } \\
\text { (h) }\end{array}$ & $\begin{array}{l}\text { Total } \\
\text { time } \\
\text { (h) }\end{array}$ & $\begin{array}{l}\% \\
\text { total } \\
\text { time }\end{array}$ \\
\hline Torpor & $\begin{array}{l}155.3 \\
\pm 9.0^{2} \\
(86)\end{array}$ & 17 & 471 & 13,355 & 98 \\
\hline Arousal & $\begin{array}{l}3.2 \\
\pm 0.2 \\
(86)\end{array}$ & 0.5 & 11.5 & 277 & 2 \\
\hline
\end{tabular}

a Mean \pm S.E. The numbers in parentheses denote sample size

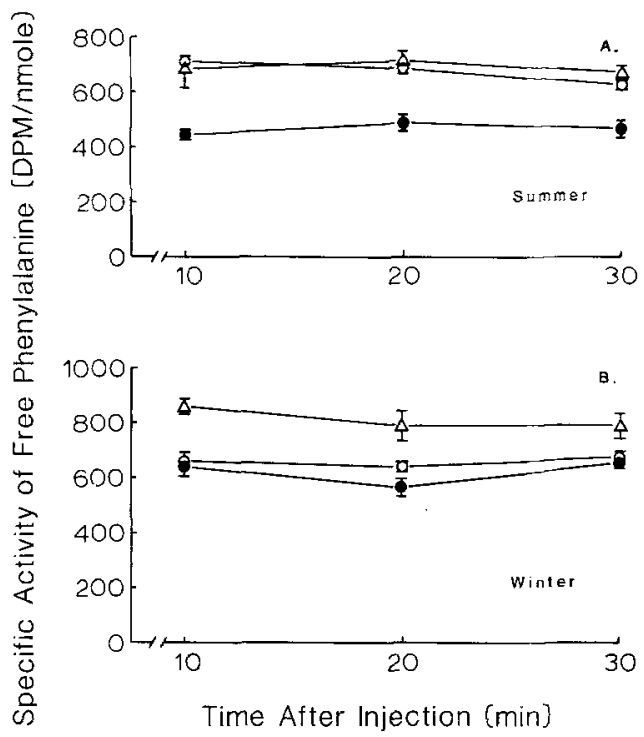

Fig. 2. The specific activity of plasma and intracellular free phenylalanine following intraperitoneal injection with $\mathrm{L}-\left[4-{ }^{3} \mathrm{H}\right]-$ phenylalanine in fasted summer bats and in hibernating bats aroused from torpor. Plasma (closed circles) and liver (open triangles) specific activities remain constant over the $30 \mathrm{~min}$ period. Pectoralis muscle (open circles) specific activity decreases significantly $(P<0.001)$ in summer bats, but remains constant in winter bats. Each point represents the mean $\pm S E$ of 5-6 independent values

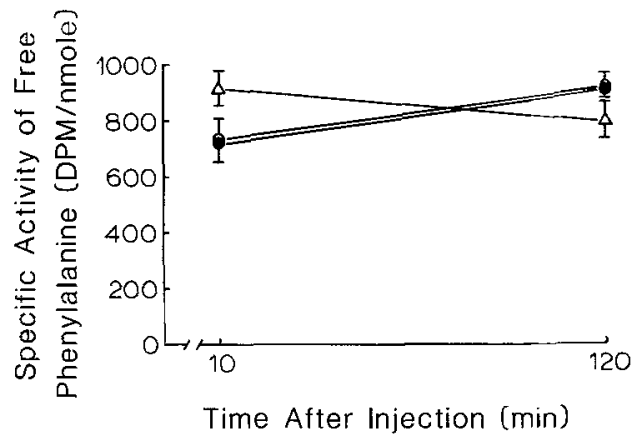

Fig. 3. The specific activity of plasma and intracellular free phenylalanine following intraperitoneal injection with $\mathrm{L}-\left[4-^{3} \mathrm{H}\right]-$ phenylalanine in torpid bats. Neither plasma (closed circles), pectoralis muscle (open circles), nor liver (open triangles) specific activity changes significantly between 10 and $120 \mathrm{~min}$ following injection. Each point represents the mean \pm SE of 4 independent values

assumptions: (1) that the labelled amino acid equilibrates rapidly with the intracellular pool, (2) that the specific activity of the free amino acid in the intracellular pool remains constant over the measurement period, and (3) that the presence of a high intracellular concentration of phenylalanine does not affect the rate of protein synthesis. The validity of the third assumption has been demonstrated explicitly in rats by Garlick et al. (1980), who showed that the injection of up to $150 \mu \mathrm{mol}$ 
Table 2. Protein synthetic rate in pectoralis muscle and liver of torpid and aroused bats after 2 months of hibernation and of fasted summer bats. All values are presented as mean $\pm \mathrm{SE}$, the numbers in parentheses denote sample size

\begin{tabular}{|c|c|c|c|}
\hline Tissue & Status & $\begin{array}{l}\text { Body } \\
\text { temperature } \\
\left({ }^{\circ} \mathrm{C}\right)^{a}\end{array}$ & $\begin{array}{l}\text { Rate } \\
\text { of protein } \\
\text { synthesis } \\
(\% / \text { day })\end{array}$ \\
\hline \multirow[t]{3}{*}{$\begin{array}{l}\text { Pectoralis } \\
\text { muscle }\end{array}$} & $\begin{array}{l}\text { Summer } \\
\text { fasted }\end{array}$ & $\begin{array}{l}35.1 \pm 0.4(17) \\
P<0.005^{b}\end{array}$ & $\begin{array}{c}8.8 \pm 2.2(17) \\
P<0.001\end{array}$ \\
\hline & $\begin{array}{l}\text { Hibernating, } \\
\text { aroused }\end{array}$ & $\begin{array}{l}33.5 \pm 0.3(15) \\
P<0.001\end{array}$ & $2.2 \pm 1.6(14)$ \\
\hline & $\begin{array}{l}\text { Hibernating, } \\
\text { torpid }\end{array}$ & $3.5 \pm 0.8(8)$ & $<1$ \\
\hline \multirow[t]{3}{*}{ Liver } & $\begin{array}{l}\text { Summer, } \\
\text { fasted }\end{array}$ & $\begin{array}{l}35.1 \pm 0.4\{17) \\
P<0.005\end{array}$ & $\begin{array}{l}63.0 \pm 27.2(12) \\
\text { N.S. }\end{array}$ \\
\hline & $\begin{array}{l}\text { Hibernating, } \\
\text { aroused }\end{array}$ & $\begin{array}{l}33.5 \pm 0.3(15) \\
P<0.001\end{array}$ & $53.3 \pm 23.9(15)$ \\
\hline & $\begin{array}{l}\text { Hibernating, } \\
\text { torpid }\end{array}$ & $3.5 \pm 0.3(8)$ & $<1$ \\
\hline
\end{tabular}

a Final rectal temperature

b The probability that adjacent means differ due to chance, using a one-tailed Student's $t$-test

of phenylalanine $/ 100 \mathrm{~g}$ of body mass does not affect the rate of protein synthesis in either muscle or liver. Regarding the first two assumptions, plasma specific activity rose rapidly following intraperitoneal injection of ${ }^{3} \mathrm{H}$-phenylalanine, reaching a plateau value in less than $10 \mathrm{~min}$ in all cases (Figs. 2, 3). Thereafter, plasma specific activity did not change significantly in any of the groups. Similarly, the specific activity of free phenylalanine in pectoralis muscle and liver samples also rose to a plateau value in less than $10 \mathrm{~min}$, indicating rapid labelling of the intracellular free phenylalanine pool. Subsequently, specific activity did not vary significantly during the measurement period in any case except that of the pectoralis muscle of summer bats (Figs. 2,3). The specific activity of free phenylalanine in the pectoralis muscle of summer bats underwent a slight, but statistically significant $(P<$ $0.001)$ decrease between 10 and 30 min post injection. However, this decrease is small enough that it does not significantly affect the estimate of pectoralis muscle protein synthesis. Therefore, it appears that the assumptions of the technique used here are valid.

The estimated rates of protein synthesis in the pectoralis muscles and liver of E. fuscus are presented in Table 2 . The rate of pectoralis muscle protein synthesis in summer bats after an overnight fast is significantly greater $(P<0.001)$ than that of hibernating bats aroused from torpor. On the

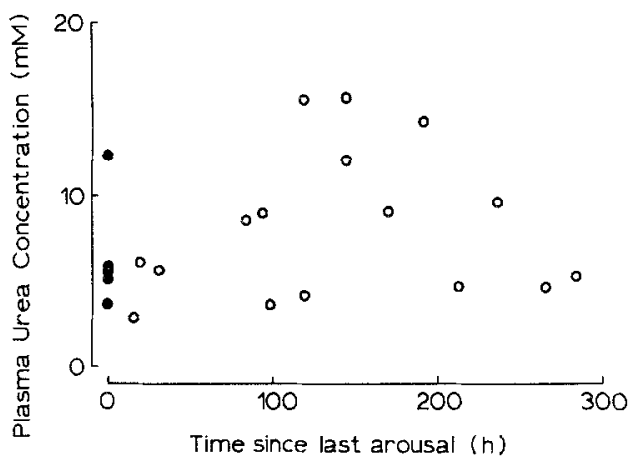

Fig. 4. The concentration of urea in the plasma of $E$. fuscus during torpor (open circles) and spontaneous arousal (closed circles)

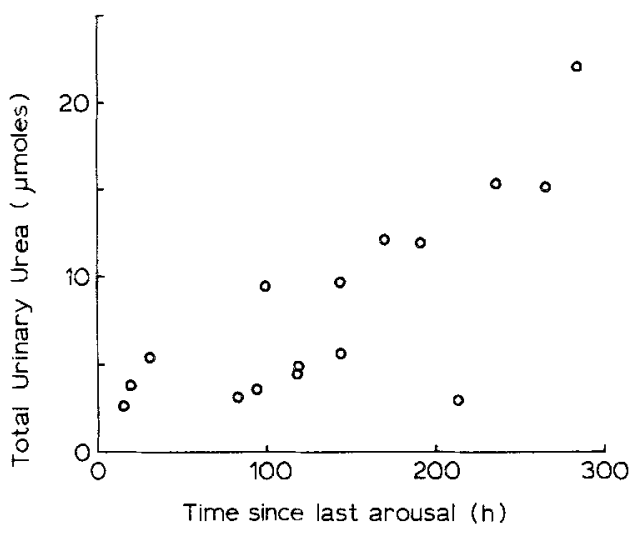

Fig. 5. The accumulation of urinary urea during torpor in $E$. fuscus

other hand, the rate of hepatic protein synthesis does not differ between fasted summer bats and hibernating bats aroused from torpor. The rates of protein synthesis in both the pectoralis muscle and liver of torpid bats were below the limit of detection of the technique used (approximately $1 \% /$ day).

\section{Plasma and urinary urea accumulation in hibernating E. fuscus}

Plasma urea concentrations are relatively high and variable in torpid bats $(2.8-14.3 \mathrm{mM})$, but they do not vary with the duration of torpor (Fig. 4). Total urinary urea increases significantly during torpor bouts of up to $300 \mathrm{~h}$ (Fig. 5). This trend is described by the equation:

$N=0.746+0.054 \mathrm{~h}$

where $\mathrm{N}$ is total urinary urea in $\mu$ moles and $\mathrm{h}$ is the time since last arousal in hours; $r=0.78$, $P<0.001, n=16$. 


\section{Discussion}

During bouts of torpor (body temperature $=3.5 \pm$ $0.3{ }^{\circ} \mathrm{C}$ ) the rates of protein synthesis in the pectoralis muscle and liver of $E$. fuscus are too low to be detected with the method employed in the present study. That is, no increase in the specific activity of protein-bound phenylalanine was detectable two hours after injection, despite rapid labelling of the free phenylalanine pools (Fig. 3, Table 2). On the other hand, significant rates of protein synthesis are evident in both the pectoralis muscle and liver of $E$. fuscus during periods of arousal (body temperature $=33.5 \pm 0.3^{\circ} \mathrm{C}$ ) after 2 months of hibernation (Table 2). The rate of protein synthesis in pectoralis muscles of aroused bats is significantly lower $(P<0.001)$ than that of summer bats following an overnight fast. The rate of hepatic protein synthesis in aroused bats does not differ significantly from that of summer bats (Table 2).

At the outset of this study it was expected that the rates of protein synthesis would be very low in both the torpid and aroused states in comparison with those of fasted summer bats. In the case of torpid bats, low synthetic rates were expected largely because of low body temperatures. The observed rates in torpid bats (Table 2) are consistent with this hypothesis. However, the extent of inhibition of protein synthesis apparent in the livers of torpid bats $\left(Q_{10}>3.5\right)$ suggests that this inhibition may involve more than a simple temperature effect. In the case of bats aroused after 2 months of hibernation, it was expected that protein synthetic rates would also be low as a result of time-dependent changes in protein metabolism similar to those of nonhibernators during prolonged fasting. In nonhibernating mammals protein synthetic rates undergo an initial decrease during the transition between the fed and postabsorptive states (Millward and Waterlow 1978; Li et al. 1979; McNurlan et al. 1979) and then a further gradual decline which may result from decreased levels of mRNA (Millward and Waterlow 1978; Li et al. 1979) and decreased degradative rates which lead to reduced availability of amino acids (Gan and Jeffay 1967; Cahill 1976). The hypothesis that protein metabolism might undergo changes during hibernation similar to those which have been observed in prolonged fasting in nonhibernators was tested by comparing bats aroused after 2 months of hibernation with summer bats after an overnight fast. These two groups of animals had similar body temperatures (Table 2) and both groups were in a fasted state. However, the summer bats had fasted for approximately $24 \mathrm{~h}$ and the hibernating bats had not had access to food for approximately 2 months. The results (Table 2) do not fully resolve this question since the rates of protein synthesis in the pectoralis muscles of aroused bats are significantly lower than those of fasted summer bats, but the rates of hepatic protein synthesis do not differ between these groups (Table 2). The high rates of hepatic protein synthesis observed in bats aroused from hibernation contrast sharply with earlier studies of hibernating ground squirrels (Spermophilus tridecemlineatus), which suggest that hepatic polyribosomes are deaggregated (Whitten et al. 1970) and that cell-free preparations of livers have significantly lower protein synthetic capacities than do those of summer squirrels (Whitten and Klain 1968).

Since the hibernating bats used in this study had had no access to food for approximately 2 months, the amino acids used for protein synthesis must have come from the breakdown of existing proteins (see Gan and Jeffay 1967). Therefore, rates of protein degradation in hibernating bats should be equal to or greater than synthetic rates and the amount by which the degradative rate exceeds the synthetic rate should equal the rates of net protein loss. This simple relationship is used here to estimate rates of protein degradation in torpid and aroused hibernating bats and in fasted summer bats. The most straightforward case is that of the torpid bats. The rate of net protein degradation during torpor can be estimated directly from the rate of appearance of urea. Urea does not accumulate in the blood of bats during bouts of torpor lasting up to $300 \mathrm{~h}$ (Fig. 4). Neither does plasma urea differ between the torpid and aroused states (Fig. 4). Urea does accumulate in the bladder during torpor and is voided during periodic arousals (Fig. 5). The rate of accumulation is very low and corresponds to a rate of loss of total body protein of less than $0.01 \% /$ day. This amounts to only about $5 \%$ of the overall decrease in total body protein which occurs during hibernation, despite the fact that torpor accounts for $98 \%$ of the time of hibernation (Yacoe 1982; Table 1). Because of the very low rate of net protein loss, the rates of protein degradation in pectoralis muscle and liver must be approximately equal to those of protein synthesis and therefore were assigned maximal values of $1 \%$ /day [this value corresponds to the upper limit placed on the estimated rates of protein synthesis (Tables 2, 4)]. The rate of loss of tissue protein during periodic arousais was calculated as the difference between the loss of protein mass in the pectoralis muscle and liver during hibernation (Table 3) and the amount which could be ac- 
Table 3. Changes in mass and protein content of the pectoralis muscle $^{a}$ and liver ${ }^{b}$ in E. fuscus during 110 days of hibernation

\begin{tabular}{|c|c|c|c|c|}
\hline Status & $\begin{array}{l}\text { Pec- } \\
\text { toralis } \\
\text { muscle } \\
\text { mass } \\
(\mathrm{g})\end{array}$ & $\begin{array}{l}\text { Total } \\
\text { pec- } \\
\text { toralis } \\
\text { protein } \\
(\mathrm{g})\end{array}$ & $\begin{array}{l}\text { Liver } \\
\text { mass } \\
(\mathrm{g})\end{array}$ & $\begin{array}{l}\text { Total } \\
\text { liver } \\
\text { protein } \\
\text { (g) }\end{array}$ \\
\hline $\begin{array}{l}\text { Pre- } \\
\text { hibernation } \\
\text { fattening }\end{array}$ & $\begin{array}{l}1.20 \pm 0.06 \\
(n=11) \\
P<0.001^{\mathrm{c}}\end{array}$ & $\begin{array}{l}0.41 \pm 0.03 \\
(n=11) \\
P<0.001\end{array}$ & $\begin{array}{l}0.73 \pm 0.05 \\
(n=11) \\
P<0.001\end{array}$ & $\begin{array}{l}0.24 \pm 0.02 \\
(n=11) \\
P<0.001\end{array}$ \\
\hline $\begin{array}{l}\text { After } \\
110 \text { days of } \\
\text { hibernation }\end{array}$ & $\begin{array}{l}0.88 \pm 0.03 \\
(n=14)\end{array}$ & $\begin{array}{l}0.22 \pm 0.01 \\
(n=14)\end{array}$ & $\begin{array}{l}0.54 \pm 0.03 \\
(n=14)\end{array}$ & $\begin{array}{l}0.11 \pm 0.01 \\
(n=14)\end{array}$ \\
\hline
\end{tabular}

a Values taken from Table 1, Yacoe (1983)

b Unpublished data collected from the same group of animals from which the muscle data were collected. Methods were identical to those described in Yacoe (1983) for the determination of pectoralis muscle mass and protein mass

c Probability that adjacent means differ due to chance, using a one-tailed Student's $t$-test

counted for by urea production during torpor. Assuming that approximately $95 \%$ of the net protein loss occurs during arousals and that arousals account for $2 \%$ of the overall time in hibernation (Yacoe 1982; Table 1), these calculations yield estimates of $20 \%$ /day and $23 \%$ /day for the fractional rate of loss of pectoralis muscle and liver protein, respectively, during periodic arousals. Therefore, the fractional breakdown rates for pectoralis muscle and liver protein during periodic arousals are estimated to be $22 \%$ /day and $73 \%$ /day, respectively (Table 4). Using similar reasoning, if the summer bats were in a steady state with respect to tissue protein mass, the fractional degradative rates would equal the fractional synthetic rates $(8.8 \%$ /day and $63 \%$ /day for pectoralis muscle and liver, respectively). However, after an overnight fast the bats were undoubtedly in negative nitrogen balance, so these estimates represent lower limits on the degradative rates in muscle and liver of fasted summer bats. Despite the crude nature of these estimates, the data suggest that the rates of protein breakdown in both pectoralis muscle and liver during periodic arousals are similar to the corresponding rates in summer bats. These data fail to support the hypothesis that protein metabolism undergoes changes during hibernation similar to those in prolonged fasting (see Felig et al. 1969; Young et al. 1973; Goldberg and St. John 1976; Felig 1979; and Le Maro et al. 1981). Rather, the high rates of protein breakdown and net protein degradation in bats aroused from hibernation are comparable to those seen in short term fasting,
Table 4. Estimated rates of net loss of protein mass and protein degradation in the pectoralis muscle and liver of E. fuscus. Calculated from data in Tables $1-3$ and Figs. 5 and 6 , as described in the Materials and methods section

\begin{tabular}{|c|c|c|c|}
\hline \multirow[t]{2}{*}{ Status } & \multirow[t]{2}{*}{ Tissue } & \multicolumn{2}{|l|}{ Rate (\%/day) } \\
\hline & & Net protein loss & Degradation \\
\hline \multirow[t]{2}{*}{$\begin{array}{l}\text { Summer, } \\
\text { fasted }\end{array}$} & $\begin{array}{l}\text { Pectoralis } \\
\text { muscle }\end{array}$ & $\geqq 0$ & $\geqq 9$ \\
\hline & Liver & $\geqq 0$ & $\geqq 63$ \\
\hline \multirow[t]{2}{*}{$\begin{array}{l}\text { Hibernating, } \\
\text { aroused }\end{array}$} & $\begin{array}{l}\text { Pectoralis } \\
\text { muscle }\end{array}$ & 20 & 22 \\
\hline & Liver & 23 & 73 \\
\hline \multirow[t]{2}{*}{$\begin{array}{l}\text { Hibernating, } \\
\text { torpid }\end{array}$} & $\begin{array}{l}\text { Pectoralis } \\
\text { muscle }\end{array}$ & 0.01 & $<1$ \\
\hline & Liver & 0.01 & $<1$ \\
\hline
\end{tabular}

when tissue protein is rapidly degraded to supply the increased gluconeogenic demand (Adibi 1976; Pozefsky et al. 1976; Chang and Goldberg 1978a, b; Li et al. 1979; Snell 1980).

Glucose oxidation appears to account for a significantly greater proportion of metabolism during periodic arousals than during torpor bouts in hibernating mammals (South and House 1967; Tashima et al. 1970; Yacoe 1982). Since glycogen stores are small (Dodgen and Blood 1956; Leonard and Wimsatt 1959; Yacoe 1982) and the contribution of glycerol is coupled to the rate of fat oxidation, the increased demand for glucose might be met by gluconeogenesis from tissue protein. The results presented here, indicating relatively high rates of net loss of pectoralis muscle and liver protein, together with the earlier observations that hepatic gluconeogenic capacity increases during hibernation (Klain and Whitten 1968) and that urea is produced in large quantities during spontaneous arousal (Galster and Morrison 1975), suggest that spontaneous arousal is a period when tissue protein is degraded to supply gluconeogenic demand. On the other hand, the very low rates of tissue protein synthesis and degradation observed in torpid bats suggest that protein metabolism is virtually suspended during torpor.

Acknowledgements. I would like to thank W.R. Dawson for his help throughout this project. This study represents a portion of a dissertation submitted in partial fulfillment of the requirements for the PhD degree. This study was supported in part by a block grant from the Horace H. Rackham School of Graduate Studies, The University of Michigan. 


\section{References}

Adibi SA (1976) Metabolism of branched-chain amino acids in altered nutrition. Metabolism 25:1287-1302

Beer JR (1955) Survival and movements of banded big brown bats. J Mammal 36:242-248

Beer JR, Richards AG (1956) Hibernation of the big brown bat. J Mammal 37:31-41

Cahill GF Jr (1976) Starvation in man. Clin Endocrinol Metab $5: 397-415$

Chang TW, Goldberg AL (1978a) The origin of alanine produced in skeletal muscle. J Biol Chem 253:3677-3684

Chang TW, Goldberg AL (1978b) The metabolic fates of amino acids and the formation of glutamine in skeletal muscle. J Biol Chem 253:3685-3695

Dodgen CL, Blood FR (1956) Energy sources in the bat. Am J Physiol 187:151-154

Felig P (1979) Starvation. In: DeGroot LJ (ed) Endocrinology, vol 3. Grune and Stratton, New York, pp 1927-1940

Felig P, Owen OE, Wahren J, Cahill GF Jr (1969) Amino acid metabolism during prolonged starvation. J Clin Invest 48: 584-594

Fricke U (1975) Tritosol: A new scintillation cocktail based on Triton X-100. Anal Biochem 63:555-558

Galster WA, Morrison PR (1975) Gluconeogenesis in arctic ground squirrels between periods of hibernation. Am J Physiol 228:325-330

Galster WA, Morrison PR (1976) Seasonal changes in body composition of the arctic ground squirrel, Citellus undulatus. Can J Zool 54:74-78

Gan JC, Jeffay H (1967) Origins and metabolism of the intracellular amino acid pools in rat liver and muscle. Biochim Biophys Acta 148:448 -459

Garlick PJ, McNurlan MA, Preedy VR (1980) A rapid and convenient technique for measuring the rate of protein synthesis in tissues by injection of $\left[{ }^{3} \mathrm{H}\right]$ phenylalanine. Biochem J 192:719-723

Goldberg AL, St John AC (1976) Intracellular protein degradation in mammalian and bacterial cells: Part 2. Annu Rev Biochem 45:747-803

Goodman MN, Ruderman NB (1980) Starvation in the rat. I. Effect of age and obesity on organ weights, RNA, DNA, and protein. Am J Physiol 239:E269-E276

Klain GJ, Whitten BK (1968) Carbon dioxide fixation during hibernation and arousal from hibernation. Comp Biochem Physiol 25:363-366

Le Maro Y, Van Kha HV, Koubi H, Dewasmes G, Girard
J, Ferre P, Cagnard M (1981) Body composition, energy expenditure, and plasma metabolites in long-term fasting geese. Am J Physiol 241:E342-E354

Leonard SL, Wimsatt WA (1959) Phosphorylase and glycogen levels in skeletal muscle and liver of hibernating and nonhibernating bats. Am J Physiol 197:1059-1062

Li JB, Higgins JE, Jefferson LS (1979) Changes in protein turnover in skeletal muscle in response to fasting. Am J Physiol 236: E222-E228

McNurlan MA, Tomkins AM, Garlick PJ (1979) The effect of starvation on the rate of protein synthesis in rat liver and small intestine. Biochem J 178:373-379

Millward DJ, Waterlow JC (1978) Effect of nutrition on protein turnover in skeletal muscle. Fed Proc 37:2283-2290

Pozefsky T, Tancredi RG, Moxley RT, Dupre J, Tobin JD (1976) Effects of brief starvation on muscle amino acid metabolism in nonobese man. J Clin Invest 57:444 449

Snell K (1980) Muscle alanine synthesis and hepatic gluconeogenesis. Biochem Soc Trans 8:205-213

South FE, House WA (1967) Energy metabolism in hibernation. In: Fisher KC, Dawe AR, Lyman CP, Schonbaum E, South FE (eds) Mammalian hibernation III. Oliver and Boyd, Edinburg, pp 305-324

Suzuki O, Yagi K (1976) A fluorometric assay for $\beta$-phenylethylamine in rat brain. Anal Biochem 75:192-200

Tashima LS, Adelstein SJ, Lyman CP (1970) Radioglucose utilization by active, hibernating, and arousing ground squirrels. Am J Physiol 218:303-309

Wang LCH (1978) Energetic and field aspects of mammalian torpor: The Richardson's ground squirrel. In: Wang LCH, Hudson JW (eds) Strategies in cold: natural torpidity and thermogenesis. Academic Press, New York, pp 109-147

Whitten BK, Klain GJ (1968) Protein metabolism in hepatic tissue of hibernating and arousing ground squirrels. Am J Physiol 214:1360-1362

Whitten BK, Schrader LE, Huston RL, Honold GR (1970) Hepatic polyribosomes and protein synthesis: Seasonal changes in a hibernator. Int J Biochem 1:406-408

Yacoe ME (1982) The maintenance of pectoralis muscle during hibernation in the big brown bat, Eptesicus fuscus. $\mathrm{PhD}$ thesis, University of Michigan, Ann Arbor

Yacoe ME (1983) Maintenance of the pectoralis muscle during hibernation in the big brown bat, Eptesicus fuscus. J. Comp Physiol

Young VR, Haverberg LN, Bilmazes C, Munro HN (1973) Potential use of 3-methylhistidine excretion as an index of progressive reduction in muscle protein catabolism during starvation. Metabolisn 22:1429-1436 